\title{
HRAVÉ UČENIE V PRÍRODOVEDNOM MÚZEU
}

EVA FARKAŠOVSKÁ - ALENA LENKOVÁ

Slovenské múzeum ochrany prírody a jaskyniarstva (SMOPaJ), sídliace v Liptovskom Mikuláši, je špecializovaným múzeom, zameraným na ochranu prírody a krajiny a jaskyniarstvo $s$ celoštátnou pôsobnostou. V rokoch 2011-2014 prešlo rozsiahlou rekonštrukciou, počas ktorej revitalizovalo svoje expozície a rozšírilo tiež možnosti svojich výstavných priestorov. Dnes tak expozície predstavujú až $1400 \mathrm{~m}^{2}$ výstavnej plochy, ktoré zahŕňajú 3 expozície. $V$ podzemí sa nachádza expozícia Kras a jaskyne Slovenska, ktorá predstavuje fenomén krasu vo všetkých súvislostiach, od hydrológie, cez povrchový a podzemný kras a jeho ochranu. Expozícia prvého poschodia s názvom Chránená príroda Slovenska - Zem, miesto pre život približuje geodiverzitu a biodiverzitu života a ich ochranu. Expozícia Chránená príroda Slovenska - Človek, hory, NATURA 2000 na druhom nadzemnom podlaží je venovaná problematike trvalej udržatel'nosti.

Vd’aka tejto rekonštrukcii múzeum doplnilo svoje expozície o množstvo audiovizuálnych a interaktívnych prvkov, ktoré rozširujú a zatraktívňujú možnosti vzdelávania.

Expozícia obsahuje medvedí brloh, model jaskyne, interaktívne prvohorné „morské dno“, mnohé zvukové efekty, ale aj digitálne technológie v podobe krátkych animovaných filmov, lektorských filmov a počítačových hier zameraných na ochranu prírody.

\section{Vzdelávanie}

Múzeum má obsahovo široký záber a vo svojich vzdelávacích aktivitách zahŕňa viaceré oblasti $\mathrm{z}$ neživej a živej prírody. $\mathrm{Z}$ tohto dôvodu sa tak okrem múzejného pedagóga, pracovníkov pre environmentálne vzdelávanie špecialistu pre MŠ a 1.stupeň ZŠ, špecialistu pre marginalizované skupiny - na vzdelávaní podiel'ajú aj odborní pracovníci so zameraním na botaniku, zoológiu, geológiu, mineralógiu, históriu a jaskyniarstvo. Vzdelávanie v múzeu je pod metodickou taktovkou riaditel'ky múzea.

Vzdelávanie poskytujeme širokej cielovej skupine - materským školám, základným školám, gymnáziám, stredným a vysokým školám, špeciálnym školám a marginalizovaným skupinám, rodinám s deṫmi, seniorom, pedagógom, ale aj odbornej a širokej verejnosti.

\section{Formy vzdelávania}

Pri vzdelávaní využívame rôzne formy, ktoré sa snažíme obohatit aj o nové moderné prvky. Medzi formy vzdelávania, ktoré v múzeu využívame, patria: Prehliadky expozícií múzea s rôznymi variantmi. Ponúkame individuálne prehliadky s využitím audiosprievodcu, komentované prehliadky pre objednané skupiny, prehliadky s odborným výkladom v slovenskom a anglickom jazyku. Pre objednané skupiny ponúkame $v z d e l a ́ v a c i e ~ p r o g r a m y$, ktoré sú rozdelené tematicky podla jednotlivých celkov a častí expozícií. Pozostávajú z prezentácie na danú tému, spojenú s workshopom, ekohrami a prehliadkou príslušnej časti expozície. Obsah programov je variabilný a prispôsobený požiadavkám a nárokom jednotlivých cielových skupín, či už sú to materské, základné, stredné, vysoké, špeciálne školy, alebo marginalizované skupiny. Celkovo ponúkame 55 programov. Výstavy sú tematicky zamerané na problematiku ochrany prírody a jaskyniarstva. Niektoré dopíňajú modely a interaktívne prvky. Školské skupiny majú k výstavám pripravené rôzne workshopy a ekohry, čo im umožňuje hravou formou lepšie pochopit a upevnit získané vedomostí z danej problematiky. Výstavy sú putovné $s$ možnostou ich zapožičania. Prednášky a besedy sú realizované na základe požiadaviek MŽP SR, partnerských organizácií, škôl, mesta a d’alších inštitúcií. Zamerané sú na propagáciu biodiverzity Slovenska a jej ochranu. Konajú sa v priestoroch múzea, ale aj mimo nich. $\mathrm{V}$ rámci prednáškovej činnosti vzdelávame aj seniorov v 4 - semestrálnom predmete Environmentálna výchova na Univerzite 3. veku Akadémie ozbrojených síl M. R. Štefánika v Liptovskom Mikuláši, kde tiež vedieme dvojsemestrálne kurzy Huby a Etnomedicína. Workshopy, ekohry a tvorivé dielne predstavujú tvorivé a hravé priblíženie rôznych

1 ŠUBOVÁ, Danka. Katalóg vzdelávacích programov Slovenského múzea ochrany prírody a jaskyniarstva pre materské školy, základné školy a stredné školy, vysoké školy, špeciálne školy a marginalizované skupiny. Liptovský Mikuláš: Slovenské múzeum ochrany prírody a jaskyniarstva, 2017. 
tém, nielen $\mathrm{v}$ rámci významných environmentálnych dní a výročí pre životné prostredie počas roka, ako sú napr. Svetový deň mokradí, Svetový deň vody, Svetový deň Zeme. Sú určené pre školy a širokú verejnoste. Terénne exkurzie, zamerané na ochranu prírody a krajiny a jaskyniarstvo, určené pre rôzne cielové skupiny (školské skupiny, seniori, pedagógovia), sú realizované na základe objednávok. Metodické semináre zahŕňajú akreditované vzdelávacie programy a neakreditované metodické semináre, určené najmä pedagógom. Detský letný tábor, ktorý nesie názov Malí ochranári, má prírodovedné zameranie a jeho cielom je poznávanie živej a neživej prírody a hlavných environmentálnych problémov formou exkurzií, hier, workshopov a praktických ukážok s odborníkmi. Organizujeme ho dennou formou, pričom každý deň je pripravená exkurzia do inej zaujímavej lokality. V roku 2020 sme zorganizovali už 5. ročník. Múzeum k vzdelávaniu prispieva aj tvorbou edičných titulov, ku ktorým okrem časopisov múzea (Slovenský kras, Naturae tutela, Sinter) patria rôzne publikácie s tematikou ochrany prírody a jaskyniarstva. Medzi d’alšie formy vzdelávania patrí aj organizovanie odborných seminárov a konferencií, odborné vedenie stredoškolských a vysokoškolských prác, príprava na biologické olympiády a sezónne prebiehajúca bylinkárska a hubárska poradňa určená pre širokú verejnost'. Ďalšími formami slúžiacimi k osvete ochrany prírody sú mnohé festivaly, celoslovenské výstavy, dni otvorených dverí a externé podujatia pre širokú verejnost', ktorých sa múzeum pravidelne zúčastňuje. Sú významným prostriedkom pre propagáciu činnosti múzea. Okrem externých workshopov sa múzeum pravidelne zúčastňuje na domácej pôde celoslovenských, celoeurópskych

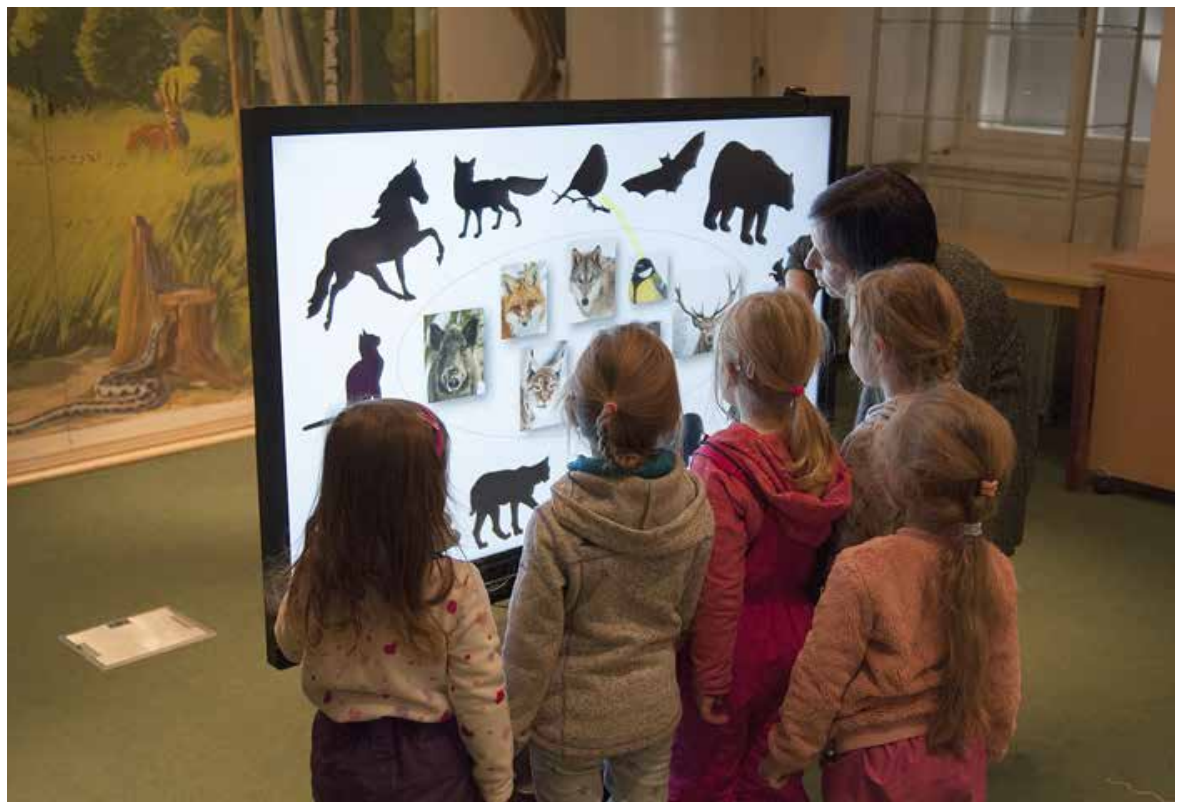

Obr. 1: Práca s interaktívnou tabul'ou (Foto: M. Oravec, Archív OPaJ).

aj celosvetových akcií, ako je napr. Noc múzeí a galérií na Slovensku, Noc literatúry, Dni európskeho kultúrneho dedičstva, Týždeň vedy a techniky a tiež organizuje vlastný Deň otvorených dverí $v$ Archíve OPaJ, Čítanie z archívu a knižnice SMOPaJ a interaktívne čítanie pre deti.

Snažíme sa držat trend aj so súčasnou dobou, a tak aj my rozširujeme naše formy vzdelávania o nové moderné prvky. Jedným $\mathrm{z}$ nich je aj mobilná aplikácia SMOPaJ, ktorú sme vytvorili v roku 2018 v spolupráci s IT odborníkom so skúsenostami s využívaním mobilných aplikácií vo výučbe na vysokých školách RNDr. Igorom Stanom a Gymnáziom M. M. Hodžu v Liptovskom Mikuláši. Mobilnú aplikáciu sme zaviedli do ponuky v školskom roku 2019/2020. Aplikácia je prepojená na expozície múzea. Je určená pre vyššie ročníky základných škôl, vyššie ročníky 8-ročných gymnázií, 4-ročné gymnáziá a stredné školy s vyučovaním biológie a ekológie. Okrem toho sme zakúpili interaktívnu tabulu na zatraktívnenie vzdelávacích programov (Obr. 1).
Tak, ako mnohé múzeá, aj naše múzeum sa muselo $\mathrm{v}$ roku 2020 popasovat so šíriacou sa pandémiou COVID 19 a s tým spojenými opatreniami, na základe ktorých sme museli prispôsobit naše aktivity aj $v$ rámci environmentálneho vzdelávania. Mnohé z nich sme presunuli do online priestoru. Na udržanie kontaktu a komunikácie nielen so školami, ale aj s návštevníkmi sme využili rôzne možnosti a formy. Sú to rôzne videoprezentácie, vd’aka ktorým sme sa zapojili napríklad do medzinárodného podujatia Európske dni archeológie s online výstavou pod názvom „Archeologické zaujímavosti z expozície Kras a jaskyne Slovenska $v$ Slovenskom múzeu ochrany prírody a jaskyniarstva $v$ Liptovskom Mikuláši“ “, ${ }^{2}$ tiež sme pripravili podujatie Hravé čítanie pre deti pod názvom Ako mnísi kláštor postavili, kde sa mohla verejnost dozvediet o histórii našej budovy. ${ }^{3}$ Každoročne pripravujeme podujatia

\footnotetext{
2 Európske archeologické dni 2020 [online] [cit. 2021-02-22]. Dostupné z: < https://www. youtube.com $/$ watch? $\mathrm{v}=\mathrm{qpKT}-\mathrm{wmgPyM}>$.

3 Ako mnísi kláštor postavili [online]. [cit. 202102-22]. Dostupné z: <https://www.youtube.com/ watch? $=$ mp79ipE2Lc8\&t $=2 \mathrm{~s}>$.
} 
pri príležitosti významných environmentálnych dní, ktoré sú spojené s workshopmi a sú určené najmä školám. Kedže v roku 2020 sa nemohli konat v priestoroch múzea, pripravili sme rôzne online materiály, z ktorých mohli nielen školy, ale aj široká verejnost čerpat množstvo informácií. Niektoré boli doplnené aj o interaktívne časti a všetky boli vol'ne stiahnutel'né. Pripravili sme tak napríklad Svetový deň vtáctva, Svetový deň biodiverzity, Svetový deň životného prostredia. Touto formou sme sprístupnili aj bylinkársku poradňu pod názvom Liečivé rastliny, byliny a dreviny. Na stránkach múzea boli sprístupnené aj panelové výstavy Kalcit a Dobšinská l'adová jaskyňa. V čase, ked' došlo k uvol'neniu opatrení a žiaci prvého stupňa sa mohli vrátit opät do škôl, no vzdelávanie ostalo čiastočne obmedzené, pripravili sme denný environmentálny program pod názvom Záhady múzejnej záhrady. Program bol určený nielen pre školské skupiny, rodiny s deṫmi, ale aj pre jednotlivcov. Prebiehal za prísnych hygienických opatrení v exteriéri múzea - v múzejnej záhrade až do neskorej jesene. Jeho hlavným cielom bolo interaktívne poznávanie biodiverzity Slovenska na rôznych stanovištiach.

Počas letných prázdnin sme pre žiakov prvého stupňa pripravili Detskú environmentálnu školu, kde bolo pre deti pripravených množstvo exkurzií a vzdelávacích aktivít, pri ktorých získali poznatky z ochrany prírody a krajiny a súčasne si precvičili vedomosti $\mathrm{z}$ jednotlivých vyučovacích predmetov. $\mathrm{V}$ mnohých úlohách a hrách sme tak prepojili biológiu $s$ matematikou, slovenčinou, angličtinou, výtvarnou, hudobnou i telesnou výchovou.

Netradične sme pripravili tiež podujatie $v$ rámci Týždňa vedy a techniky pod názvom Tajomstvá mikrosveta formou online sútaže. Sútaž bola zameraná na poznávanie mikroskopických aj makroskopických detailov prírody. Úlohou sútažiacich bolo správne pomenovat', čo sa skrýva na vybraných snímkach. Malí aj vel'kí sa tak pri poznávaní mikrosveta zahrali na vedcov a pátračov. Do sútaže sa mohli zapojit jednotlivci žiaci, študenti, dospelí, ale aj celá rodina. Tí najlepší získali zaujímavé vecné ceny.

\section{Interaktivita}

Zámerom múzea je vo vzdelávaní poskytovat najmä možnosti interaktívneho a zážitkového vzdelávania. Počas mnohých vzdelávacích programov, workshopov, tvorivých dielní, ekohier a tiež terénnych exkurzií sa tak snažíme vedomosti sprostredkovat hravou formou. Pre niektorých ludí nudnú históriu tak môžeme podat zábavne alebo pre iných nezáživnú geológiu priblí̌zit prostredníctvom pokusov či hier.

\section{Príklady dobrej praxe}

V našom vzdelávaní sa nám osvedčilo učenie formou vlastného zážitku a skúsenosti. Kladieme dôraz na možnosť kontaktu s objavovanými predmetmi a javmi, čím návštevníci môžu pochopit svet vedy lahšie a zábavnejšie. Rozmanitost̉ našich rastlín poznávame pomocou živých ukážok, pri ktorých využívame aj iné zmysly (Obr. 2). Pri úlohách poznávame bylinky podla čuchu, rôzne prírodniny hádame pomocou hmatu. Chut zase používame pri rozoznávaní zloženia minerálnych vôd alebo poznávanie byliniek pri ochutnávaní bylinkových čajov. Tieto zmyslové úlohy a cvičenia využívame nielen pri výučbe zdravých detí, ale aj v prípade marginalizovaných skupín.

Ríšu živočíchov spoznávame od mikroskopických foriem až po naše najväčšie cicavce. Najmä pri vzácnych a ohrozených druhoch využívame prácu so zbierkovými predmetmi múzea, ktoré môžu účastníci naživo vidiet', poznávat', a tak sa na príbehu zbierky učit o ich živote, výskyte, ohrození a ochrane. Oblúbeným medzi všetkými vekovými kategóriami je pozorovanie pomocou mikroskopickej techniky. Prostredníctvom nej demonštrujeme nielen mikroskopické organizmy,

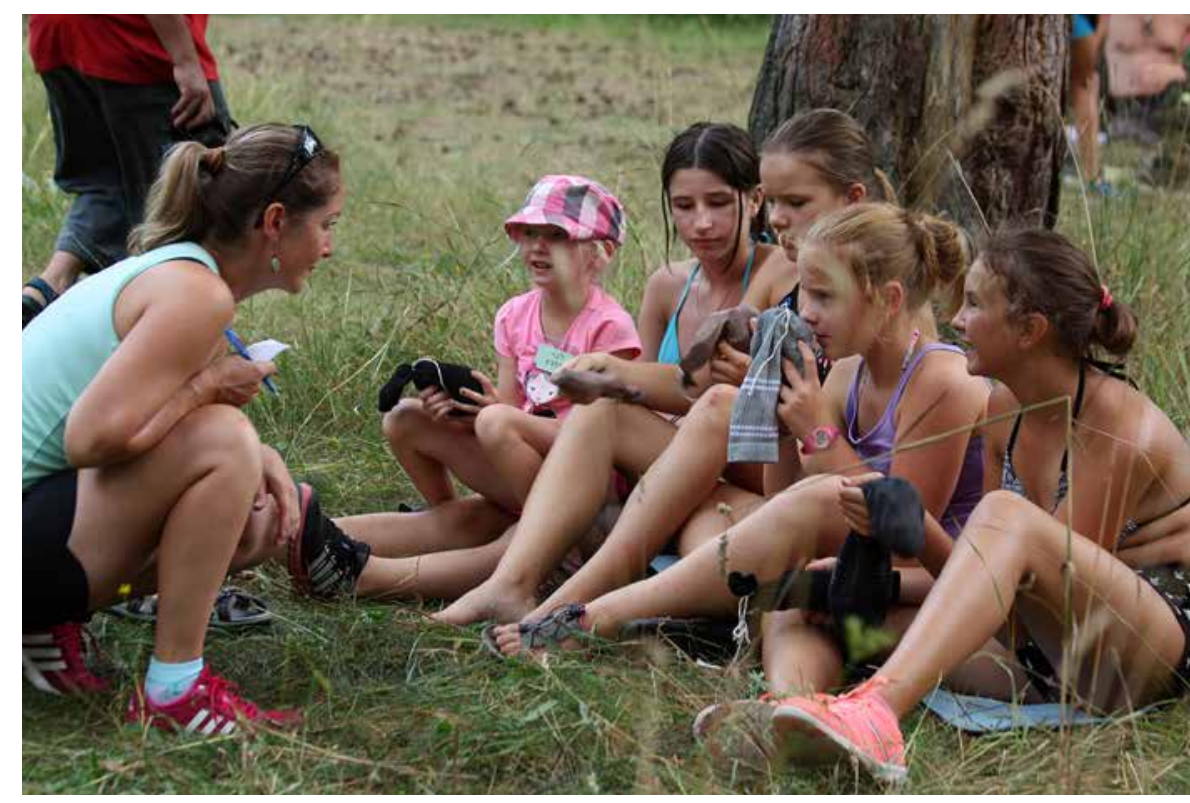

Obr. 2: Poznávanie liečivých bylín čuchom (Foto: A. Lenková, Archív OPaJ). 


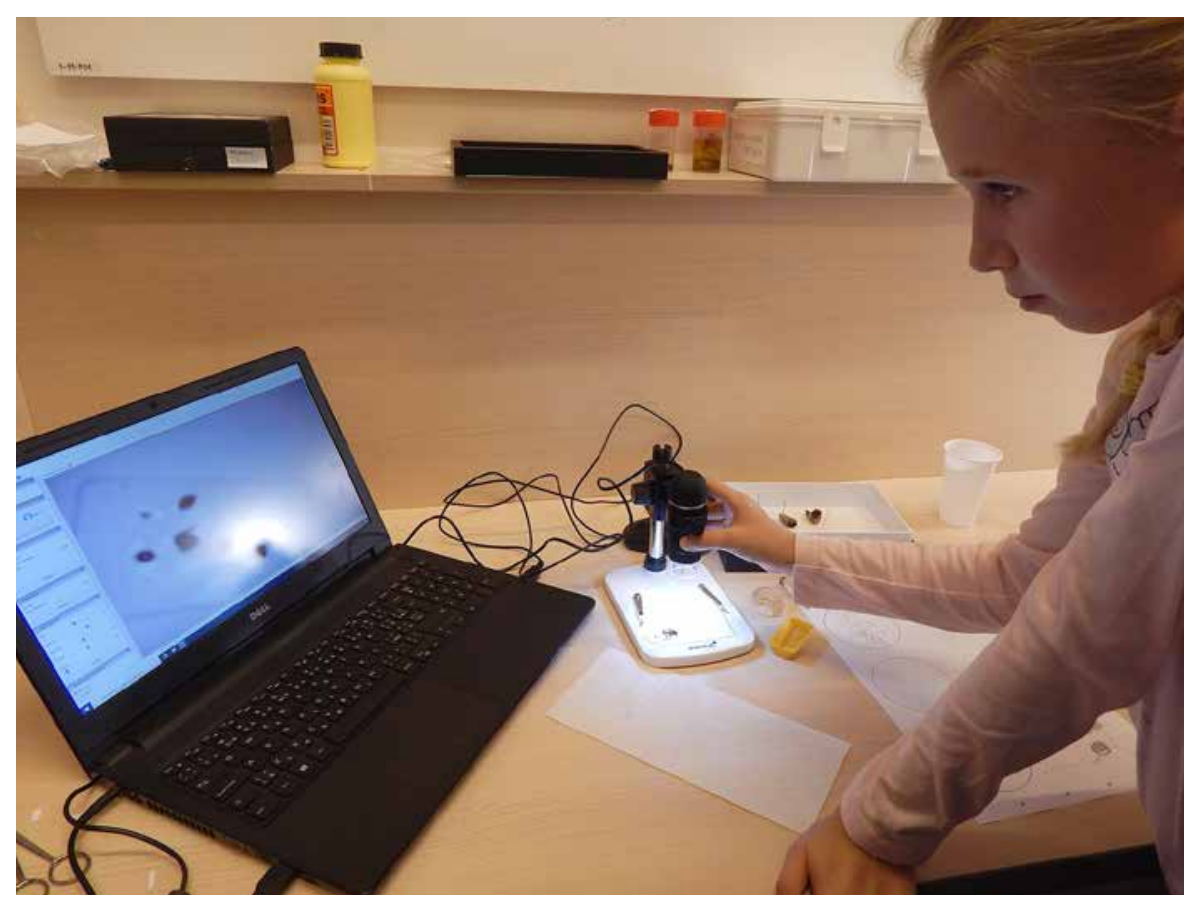

Obr. 3: Týždeň vedy a techniky 2019 (Foto: E. Farkašovská, Archív OPaJ).

ale aj iné okom neviditelné detaily makroskopických objektov. Pozorujeme tak štruktúru minerálov, húb, rastlín aj živočíchov. Návštevníci si pripravujú vlastné preparáty, a tak sami ovplyvňujú výber pozorovaných predmetov (Obr. 3).

Či je leto, či je zima, radi vzdelávame $\mathrm{v}$ teréne, kde si zaujímavosti zo zoológie, botaniky, geológie alebo archeológie priamo ukážeme. Deti l'ahšie pochopia vysvetlované poznatky a okrem teoretických znalostí tu tiež dostávajú praktickú skúsenoste s technikami výskumu. Vyskúšajú si odchyt bezstavovcov pomocou entomologickej sietky, ryžujú zlato, alebo skúmajú horniny pomocou geologického kladivka (Obr. 4). Ked’že sme jediné slovenské múzeum so špecializáciou na jaskyniarstvo, $v$ našich programoch nesmú chýbat jaskyne. Mnohé sme spolu s malými či vel'kými návštevníkmi navštívili, sami si vyskúšali jaskyniarsku výstroj a techniku, zahrali sa na jaskynných umelcov pri tvorbe vlastných jaskynných malieb, naučili sa o svetle v jaskyniach v minulosti a dnes, meraní jaskýň, jaskynnej výzdobe alebo o živote $v$ jaskyniach. Hravá paleontológia $\mathrm{v}$ podobe rôznych skladačiek, či pátraní pri vlastných „vykopávkach“, umožní nahliadnut do histórie života na našej Zemi. Na vzdelávanie využívame aj múzejnú záhradu, ktorá predstavuje ukážku viacerých biotopov a v malom „hornináriu“ tiež demonštráciu geologickej stavby Slovenska. V jej areáli sme vytvorili „ekozáhradku“ živú záhradku, využitelnú na environmentálnu výučbu detí, v ktorej majú deti, žiaci a študenti možnost prakticky si vyskúšat úkony v záhrade. Pozostáva z vyvýšených záhonov, ktoré sa každoročne vysádzajú viacerými druhmi byliniek a zeleniny (Obr. 5). Malí aj vel'kí návštevníci sa môžu mnohému naučit aj počas hry v environmentálnej oddychovej zóne s interaktívnymi edukačnými prvkami.

V našom vzdelávaní nám nie sú cudzie ani náročné témy ako je genetika. Pri vzdelávaní na túto tému pomáha animovaný lektorský film vytvorený pri inovácii expozícií múzea. Pedagógovia radi využívajú možnost' vysvetlenia zložitých tém z genetiky, alebo napr. fotosyntézu rastlín prostredníctvom týchto jednoduchých a lahko pochopitel'ných animácií.

Pre dobro veci sa neváhame obliect' aj do mnohých kostýmov (dinosauri, vlčice, sovy, lienky, mravce, elfovia a pod.), ktorými didakticky namotivujeme $\mathrm{k}$ danej téme najmä najmenších návštevníkov.

\section{Záver}

Prírodovedné múzeá nielen na Slovensku významným spôsobom prispievajú k neformálnemu vzdelávaniu všetkých vekových skupín. Sú priestorom pre výučbu mnohých tém. Aj SMOPaJ sa vo svojich aktivitách venuje environmentálnej výchove, vzdelávaniu a osvete, čím sa podiel’a na neformálnom vzdelávaní v oblasti ochrany prírody a krajiny a ochrany životného prostredia.

Rozsah tém vzdelávania $\mathrm{v}$ múzeách závisí od rozsahu zbierok, expozícií alebo personálnych možností. Múzeá pri svojej práci nezabúdajú na svoju hlavnú odbornú činnost', ktorou je zbierkotvorná činnost', ale aj využívanie a sprístupňovanie zbierok verejnosti. Možnost kontaktu návštevníka so zbierkovým predmetom sa tak stáva unikátnym prostriedkom pri vzdelávaní, s ktorým sa žiaci na školách nestretávajú.

V mnohých múzeách (zameraných predovšetkým na spoločenské vedy) vzdelávanie školských skupín často zabezpečuje najmä špecializovaný múzejný pedagóg. Odborní pracovníci sa tak s návštevníkom pri vzdelávaní stretajú zriedka. Mnohé prírodovedné múzeá na Slovensku nemajú špecializovaných múzejných pedagógov, ich úlohu často zastávajú 


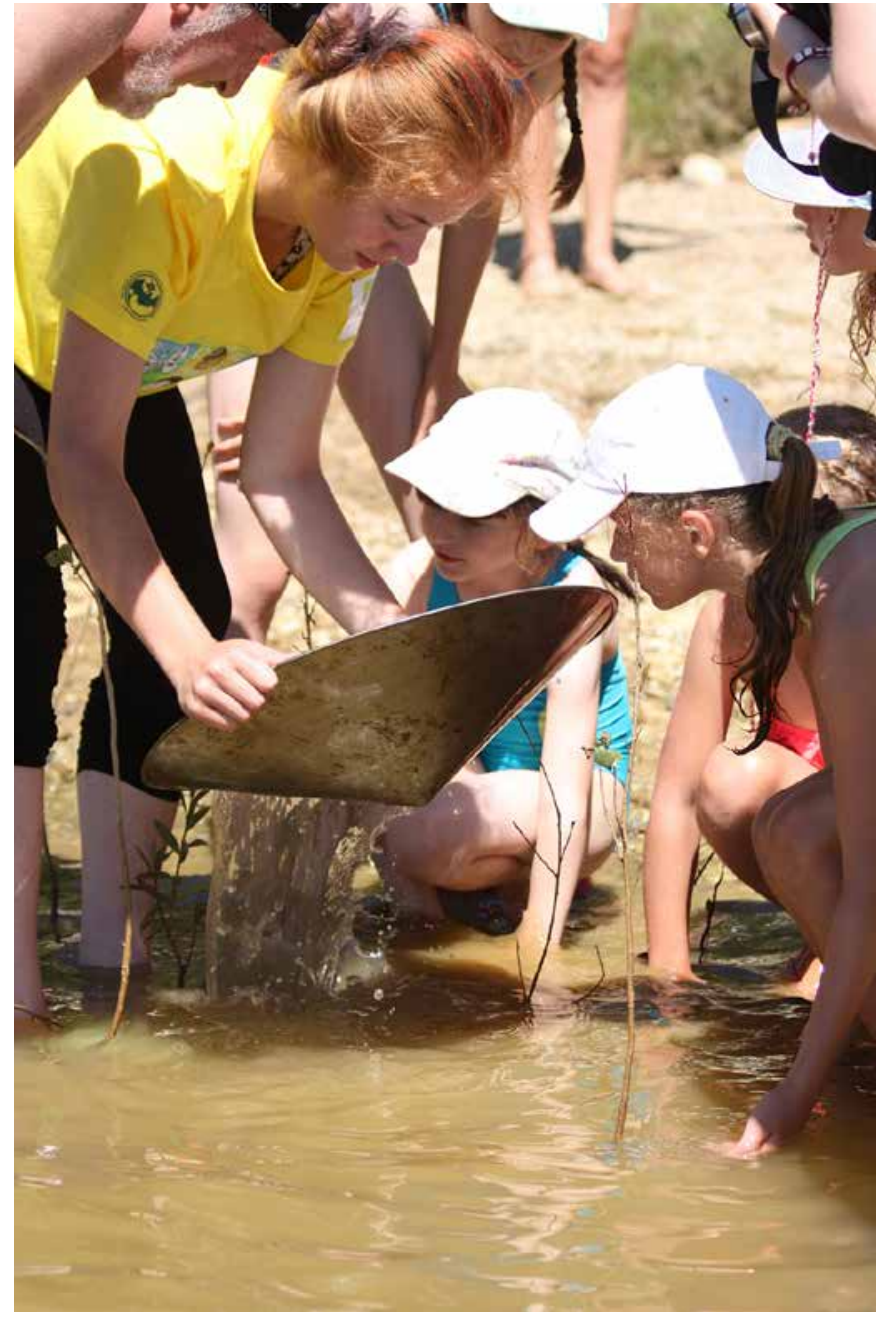

Obr. 4: Ryžovanie zlata počas detského letného tábora - Malí ochranári (Foto: A. Lenková, Archív OPaJ).

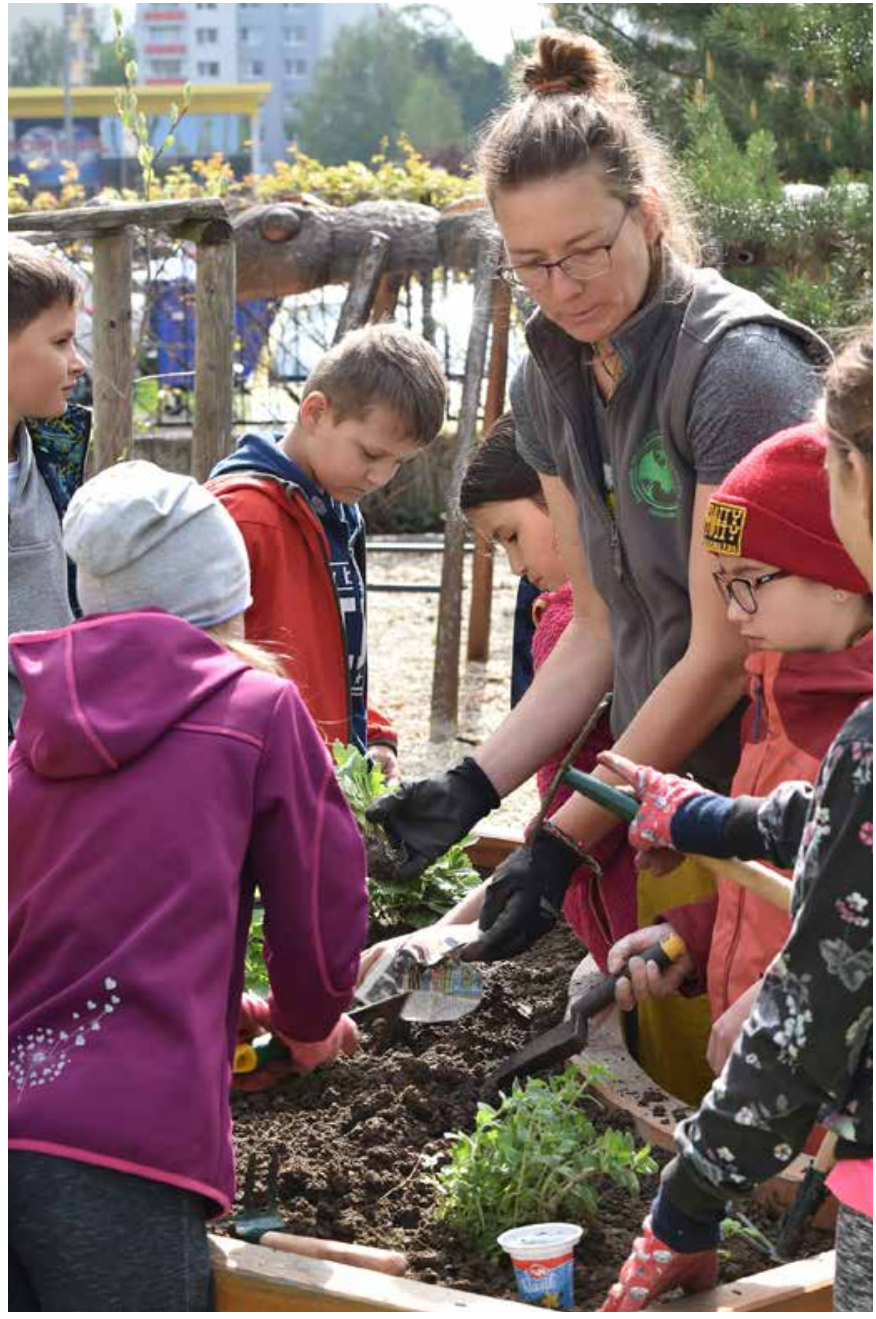

Obr. 5: Vzdelávanie v ekozáhradke (Foto: M. Oravec, Archív OPaJ). lektori a odborní pracovníci, mnohokrát $\mathrm{v}$ podobe kumulovaných funkcií. Nakol'ko SMOPaJ má odborníkov na viaceré oblasti, ako je geológ, botanik, zoológ, paleontológ, archeológ alebo jaskyniar, je schopné poskytnút pre návštevníkov široký záber vedomostí a najmä skúseností v oblasti prírodných vied. Okrem nich sa na vzdelávaní podielajú pedagógovia z praxe (múzejný pedagóg, špecialista pre MŠ a 1. stupeň ZŠ), čím zabezpečuje aj metodicky a didakticky kvalitné vzdelávanie.

Dnešná mládež trávi množstvo času za počítačmi a v školách sa výučba prírodovedných predmetov často minimalizuje na memorovanie faktov, čím sa výrazne vzd’alujú od samotnej prírody. Nadchnút žiakov pre vzdelávanie najmä v pubertálnom veku je nelahkým orieškom pre učitela či lektora pri neformálnom vzdelávaní. Práve preto je vel’mi dôležitá motivácia žiaka, ktorej úlohou je v pozitívnom zmysle ovplyvnit spoločenské vedomie vo vztahu $\mathrm{k}$ prírodným vedám a navrátit záujem o ne. Žiaci nesmú prírodné vedy vnímat ako niečo nudné a nezrozumitel'né. Základným predpokladom motivácie je poskytnút im pocit, že prírodným vedám rozumejú a že poskytujú nástroj na pochopenie, ako svet okolo funguje. ${ }^{4}$ Výučba prírodných vied, založená na

4 Bádatel'ské aktivity $v$ prírodovednom vzdelávaní, čast’ A. Bratislava: Štátny pedagogický ústav, 2016. bádaní IBSE (Inquiry based science education), je svetový trend, ktorý nadobúda v súčasnosti vel'ký význam. Mení prístup k výučbe a poskytuje žiakom príležitost', aby skúmali javy samostatne a mali tak možnosṫ zažit pocit objavovania..$^{5}$ SMOPaJ kladie dôraz pri vzdelávaní na interaktivitu, pri ktorej využíva rôzne hry, pokusy, tvorivé dielničky či vzdelávanie $\mathrm{v}$ teréne, pretože možnost vidiet', počut', chytit či zažit to, o čom sa učíme, je pre našich návštevníkov nenahraditel'ným a nezabudnutel'ným zážitkom.

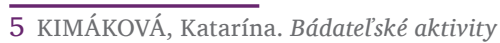
v prírodovednom vzdelávaní, čast' B Biológia. Bratislava: Štátny pedagogický ústav, 2015. 
POUŽITÁ LITERATÚRA:

Ako mnísi kláštor postavili [online]. [cit. 2021-02-22]. Dostupné z: $<$ https://www.youtube.com/ watch? $\mathrm{v}=$ mp79ipE2Lc8\& $\mathrm{t}=2 \mathrm{~s}>$. Bádatel'ské aktivity $v$ prírodovednom vzdelávaní, čast' A. Bratislava: Štátny pedagogický ústav, 2016. ISBN 978-80-8118-155-9.

Európske archeologické dni 2020 [online]. [cit. 2021-02-22]. Dostupné z: <https:// www.youtube.com/watch? $\mathrm{v}=\mathrm{qpKT}$ wmgPyM >.
KIMÁKOVÁ, Katarína. Bádatel'ské aktivity $v$ prírodovednom vzdelávaní, čast̉ B Biológia. Bratislava: Štátny pedagogický ústav, 2015. ISBN 978-80-8118-151-1.

ŠUBOVÁ, Danka. Katalóg vzdelávacích programov Slovenského múzea ochrany prírody a jaskyniarstva pre materské školy, základné školy a stredné školy, vysoké školy, špeciálne školy a marginalizované skupiny. Liptovský Mikuláš: Slovenské múzeum ochrany prírody a jaskyniarstva, 2017. ISBN 978-80-88924-97-5.

\section{EVA FARKAŠOVSKÁ}

Slovenské múzeum ochrany prírody a jaskyniarstva, Liptovský Mikuláš, Slovensko

eva.farkasovska@smopaj.sk

\section{ALENA LENKOVÁ}

Slovenské múzeum ochrany prírody a jaskyniarstva, Liptovský Mikuláš, Slovensko alena.lenkova@smopaj.sk 